\title{
Effect of polymer and plant protectants based seed treatment on crop performance in wheat (Triticum aestivum $\mathrm{L}$.)
}

\author{
Anubhav Thakur*, Karam Chand Dhiman and Rajesh Kanwar \\ Chaudhary Sarwan Kumar Himachal Pradesh, Krishi Vishvavidyalaya, Palampur - 176062 (Himachal Pradesh), India
}

Article history:

Received: 11 June, 2021

Revised: 25 Aug., 2021

Accepted: 07 Sept., 2021

\section{Citation:}

Thakur A, Dhiman KC and Kanwar R. 2021. Effect of polymer and plant protectants based seed treatment on crop performance in wheat (Triticum aestivum L.). Journal of Cereal Research 13 (Spl-1): 92-96. http://doi. org/10.25174/2582-2675/2021/115272

\section{*Corresponding author:}

E-mail: anubhavthakur97@gmail.com

(c) Society or Advancement of Wheat and Barley Research

\begin{abstract}
A field experiment was undertaken to extrapolate the effect of different polymer and plant protectants based seed treatment on yield and yield components of wheat (Triticum aestivum cv. HPW155). Results interpret that different polymer based seed treatment had significant effect on tillers per plant, plant height $(\mathrm{cm})$, spike length $(\mathrm{cm})$, spikes per plant, spikelet per spike, seeds per spike, 1000-seed weight $(\mathrm{g})$, seed yield per plot $(\mathrm{kg})$, seed yield (q/ ha) except days to $50 \%$ flowering and days to $75 \%$ maturity which had shown non-significant differences. Treatments, $T_{6}$ - polymer + Vitavax $200 @ 2 \mathrm{~g} / \mathrm{Kg}$ of seed and $\mathrm{T}_{5}$ - Vitavax $200 @ 2 \mathrm{~g} / \mathrm{Kg}$ seed had shown significant superiority for tillers per plant, plant height (cm), spike length $(\mathrm{cm})$, spikes per plant, spikelets per spike, 1000 - seed weight, seed yield per plot (kg), and seed yield (q/ ha) over control ( $T_{1}$ - control). Treatment $T_{6}$ had shown $14.7 \%$ gain in seed yield as comapred to untreated control $\left(\mathrm{T}_{1}\right)$.
\end{abstract}

Keywords: Crop performance, polymer coating, seed, wheat, 1000 seed weight

\section{Introduction}

Wheat (Triticum aestivum L.) is a cereal grass of the gramineae family having its geographical origin in Middle East (Miller, 1987). It is a leading food crop that has been described as the 'King of Cereals' because of its acreage, high productivity and the prominent position in the International food grain trade. Wheat provides a large fraction of the dietary protein and total food supply, and is grown throughout the world, in a wide variety of climates. Modern seed production system requires a high degree of precision in crop establishment. The need for high plant population density and uniform plant stand requires high quality wheat seed that will consistently produce rapid and uniform seedlings. The use of high quality seed is among the best practices for obtaining maximum crop yield. These seeds are more likely to achieve a high performance when exposed to different environmental conditions, expressed in a high per centage and speed of emergence, good stand establishment, good initial seedling development and increased final production (Tillmann and Miranda, 2006). It is the seed physiological and sanitary quality which determines their performance in the field i.e. the proper establishment of plants that is essential for satisfactory level of productivity and final product quality (Nascimento, 2011). After sowing, seeds are still exposed to biotic and abiotic environmental factors (Delouche, 2005) and agricultural soils have many pathogenic microorganisms that may interact with seeds and seedlings (Munkvold and O'Mara, 2002) and reduce their performance by causing seed rot, root rot and seedling death (Pinto, 2000). Phytophagous insects in the soil can also damage seedlings (Girolami, 2009) and significantly reduce the plant population. Under these conditions seed treatment with polymer, fungicides and insecticides is an ideal approach for improving seed and seedling performance of wheat under field conditions. Keeping this in the view present research was formulated 
to study the effect polymer based different seed treatment on crop performance in wheat.

\section{Materials and Methods}

The current study was conducted at Department of Seed Science and Technology, CSKHPKV Palampur. Seed treatment was done manually during December 2018 on carry over seeds of rabi 2017-18 seasons and achieved uniform coating of seeds. Ten treatments viz; $\mathrm{T}_{1}$ - untreated control, $\mathrm{T}_{2}$ - polymer coating (Polykote @ $3 \mathrm{ml} / \mathrm{Kg}$ ) of seed, $\mathrm{T}_{3}$ - flowable Thiram (Royal flow 40SC) @ $2.4 \mathrm{ml} /$ $\mathrm{kg}, \mathrm{T}_{4}$ - polymer + flowable Thiram (Royal flow $40 \mathrm{SC}$ ) @ $2.4 \mathrm{ml} / \mathrm{Kg}$ seed, $\mathrm{T}_{5}$ - Vitavax 200 (containing Thiram 37.5\% and Carboxil 37.5\%) @ 2 g/Kg seed, $\mathrm{T}_{6}$ - polymer + Vitavax 200 (containing Thiram, 37.5\% and Carboxil, 37.5\%)@ $2 \mathrm{~g} / \mathrm{Kg}$ of seed, $\mathrm{T}_{7}$ - Imidacloprid (Gaucho) @ 4 $\mathrm{ml} / \mathrm{Kg}$ seed, $\mathrm{T}_{8}$ - polymer + Imidachloprid (Gaucho) @ $4 \mathrm{ml} / \mathrm{Kg}$ seed, $\mathrm{T}_{9}$ - polymer + flowable Thiram (Royal flow $40 \mathrm{SC}$ ) @ 2.4 ml/Kg seed + Imidacloprid (Gaucho) @ $4 \mathrm{ml} / \mathrm{Kg}$ seed, $\mathrm{T}_{10}$ - polymer + Vitavax 200 (containing Thiram, 37.5\% and Carboxil, 37.5\%) @ 2 g/Kg of seed + Imidacloprid (Gaucho) @ 4 ml/Kg seed were evaluated in randomized block design (RBD) with three replications after one year of storability. Ten plants from each plot were selected randomly to record the data on days to $50 \%$ flowering, days to $75 \%$ maturity, tillers per plant, plant height $(\mathrm{cm})$, spike length $(\mathrm{cm})$, spikes/spike, spikelets per spike, seeds per spike, 1000 seed weight (g), seed yield/plot $(\mathrm{kg})$, seed yield ( $\mathrm{q} / \mathrm{ha})$. The recorded data was statistically analyzed using software OPSTAT(Sheoranet al., 1998)

\section{Results and Discussion}

The statistically analyzed data showed that different seed treatments significantly influenced the tillers per plant, plant height $(\mathrm{cm})$, spike length $(\mathrm{cm})$, spikes per plant, spikelets per spike, seeds per spike, 1000 seed weight (g), seed yield per plot $(\mathrm{Kg})$ and seed yield (q/ ha). Days taken to 50 per cent flowering did not differ significantly due to different seed treatments. However, the lowest number of days taken to 50 per cent flowering was obtained in $\mathrm{T}_{6}$ - polymer + Vitavax $200 @ 2 \mathrm{~g} / \mathrm{Kg}$ of seed (123.00), while the highest days was recorded in $\mathrm{T}_{1}$ - control (126.00) and $\mathrm{T}_{4}$ - polymer + flowable Thiram @ $2.4 \mathrm{ml} / \mathrm{Kg}$ seed (126.0) (Table 1). Similar trends were reported in days to 75 per cent maturity which does not differ significantly due to different seed treatments (Table 1). Similar results were reported by Raju et al. (2019) who had recorded that polymer and Thiram had non - significant influence on days to maturity in maize.

The number of tillers per plant recorded was significantly influenced by different seed treatments. Significantly higher tillers per plant over $\mathrm{T}_{1}$ - control (2.40) was observed for the treatment $\mathrm{T}_{6}-(4.80)$, followed by $\mathrm{T}_{5}$ - (4.46), $\mathrm{T}_{8}$ - (3.93), $\mathrm{T}_{7}$ - (3.60), $\mathrm{T}_{10}$ - (3.40), $\mathrm{T}_{3}$ - (3.20), $\mathrm{T}_{2}$ - polykote@ $3 \mathrm{ml} / \mathrm{Kg}$ of seed (3.00), $\mathrm{T}_{9}$ - (2.80) and $\mathrm{T}_{4}-(2.65)$ (Table 1). Similar results are recorded by Tiwari et al. (2015) and Freiberg et al. (2020) in wheat. Plant height varied significantly for all the treatments. Average plant height recorded was 95.54 $\mathrm{cm}$. Significantly higher plant height in comparison to $\mathrm{T}_{1}$ - control $(92.00 \mathrm{~cm})$ was recorded for treatment $\mathrm{T}_{6}-(98.47 \mathrm{~cm})$ followed by $\mathrm{T}_{5}-(98.00 \mathrm{~cm}), \mathrm{T}_{8}-(97.44$ $\mathrm{cm}), \mathrm{T}_{7}-(96.56 \mathrm{~cm}), \mathrm{T}_{10}-(95.93 \mathrm{~cm}), \mathrm{T}_{3}-(95.16 \mathrm{~cm})$, $\mathrm{T}_{2}-(94.70 \mathrm{~cm}), \mathrm{T}_{9}-(94.00)$ and $\mathrm{T}_{4}-(93.23 \mathrm{~cm})($ Table 1). Similar results were reported by Sumalata et al. (2017) and Sharma et al. (2017) in maize.

The spike length was significantly influenced by different seed treatments. Significantly higher spike length was recorded for $\mathrm{T}_{6}-(12.30 \mathrm{~cm})$ followed by $\mathrm{T}_{5}-(11.73 \mathrm{~cm})$, $\mathrm{T}_{8}-(11.13 \mathrm{~cm}), \mathrm{T}_{7}-(10.44 \mathrm{~cm}), \mathrm{T}_{10}-(9.93 \mathrm{~cm}), \mathrm{T}_{3}-(9.46$ $\mathrm{cm}), \mathrm{T}_{2}-(8.86 \mathrm{~cm}), \mathrm{T}_{9}-(8.57)$ and $\mathrm{T}_{4}-(8.28 \mathrm{~cm})$ (Table 1$)$. Significantly higher spikes per plant was observed for the treatment $\mathrm{T}_{6}-(4.60)$ followed by $\mathrm{T}_{5}-(4.20), \mathrm{T}_{8}-(3.80)$, $\mathrm{T}_{7}-(3.52), \mathrm{T}_{10}-(3.20), \mathrm{T}_{3}-(2.97), \mathrm{T}_{2}-(2.75), \mathrm{T}_{9}(2.54)$ and $\mathrm{T}_{4}$ - (2.33) (Table 1). Similar results are recorded by Tiwari et al. (2015) in wheat.

The numbers of spikelets per spike was significantly influenced by different seed treatments. Significantly higher spikes was observed for treatment $\mathrm{T}_{6}$ (18.60) followed by $\mathrm{T}_{5}(18.20), \mathrm{T}_{8}$ (18.00), $\mathrm{T}_{7}$ (17.80), $\mathrm{T}_{10}$ (17.60), $\mathrm{T}_{3}$ (17.40), $\mathrm{T}_{2}$ (17.20), $\mathrm{T}_{9}$ (17.00) and $\mathrm{T}_{4}$ (16.90) (Table 1). Significantly higher seeds per spike were observed for treatment $\mathrm{T}_{6}(46.50)$ followed by $\mathrm{T}_{5}(45.50), \mathrm{T}_{8}$ (45.00), $\mathrm{T}_{7}$ (44.50), $\mathrm{T}_{10}$ (44.00), $\mathrm{T}_{3}$ (43.50), $\mathrm{T}_{2}$ (43.00), $\mathrm{T}_{9}$ (42.50) and $\mathrm{T}_{4}$ (42.25) (Table 1 and Fig. 1). Similar results were reported by Tiwari et al. (2015) in wheat.

Average weight of 1000 seeds recorded for all treatments was $49.11 \mathrm{~g}$. Significantly higher 1000 seed weight was recorded for all the treatments in comparison to $\mathrm{T}_{1}$ control $(47.00 \mathrm{~g}) . \mathrm{T}_{6}(51.37 \mathrm{~g})$ of seed exhibited highest 1000 seed weight followed by $\mathrm{T}_{5}(50.77 \mathrm{~g}), \mathrm{T}_{8}(50.22 \mathrm{~g}), \mathrm{T}_{7}$ (49.83 g), $\mathrm{T}_{10}(49.34 \mathrm{~g}), \mathrm{T}_{3}(49.00 \mathrm{~g}), \mathrm{T}_{2}(48.33 \mathrm{~g}), \mathrm{T}_{9}(47.92$ 
$\mathrm{g}$ ), and $\mathrm{T}_{4}(47.37 \mathrm{~g})$ (Table 1 and Fig. 1). Similar results were reported by Shakuntla et al. (2010) in sunflower, Selvakumar et al. (2015) in wheat, Sumalata et al. (2017) in maize and Sharma et al. (2017) in maize.

Average seed yield per plot across various treatments was recorded as $1.62 \mathrm{Kg}$ perplot. Significantly higher seed yield per plot in comparison to $\mathrm{T}_{1}$ control $(1.50$ $\mathrm{Kg}$ ) was recorded for treatment $\mathrm{T}_{6}(1.72 \mathrm{Kg})$, followed by $\mathrm{T}_{5}(1.70 \mathrm{Kg}), \mathrm{T}_{8}(1.67 \mathrm{Kg}), \mathrm{T}_{7}(1.65 \mathrm{Kg}), \mathrm{T}_{10}(1.63 \mathrm{Kg})$, $\mathrm{T}_{3}(1.61 \mathrm{Kg}), \mathrm{T}_{2}(1.59 \mathrm{Kg}), \mathrm{T}_{9}(1.57 \mathrm{Kg})$, and $\mathrm{T}_{4}(1.55 \mathrm{Kg})$ (Table 1). Similar results were reported by Chikkanna et al. (2000) in groundnut, Shakuntla et al. (2010) in sunflower, Sumalata et al. (2017) and Sharma et al. (2017) in maize. The seed yield per hectare was computed from the seed yield per plot. Significantly higher seed yield ( $\mathrm{q} / \mathrm{ha}$ ) in comparison to $\mathrm{T}_{1}$ control (45.45 unit $\mathrm{q} / \mathrm{ha}$ ) was recorded in $\mathrm{T}_{6}(52.12 \mathrm{q})$, followed by $\mathrm{T}_{5}(51.51 \mathrm{q})$, $\mathrm{T}_{8}(50.60 \mathrm{q}), \mathrm{T}_{7}(50.00 \mathrm{q}), \mathrm{T}_{10}(49.39 \mathrm{q}), \mathrm{T}_{3}(48.78 \mathrm{q}), \mathrm{T}_{2}$ (48.18 q), $\mathrm{T}_{9}(47.57 \mathrm{q})$, and $\mathrm{T}_{4}(46.96 \mathrm{q})$ (Table $1 \&$ Fig 1). Similar results are reported by Kumar et al. (2014) in pigeon pea, Tiwari et al. (2015) in wheat, Sumalata et al. (2017), Bony et al. (2017) in soybean and Sharma et al. (2017) in maize.

During present study better spikes per plant, spikelets per spike, 1000-seed weight and seed yield (q/ ha) was recorded for seed treatments with polymer and fungicides. Therefore, seed treatments with polymer and fungicides could be used to enhancing seed yield of wheat seeds.

\section{Conclusion}

Results had shown that different polymer based seed treatment had significant effect on tillers per plant, plant height $(\mathrm{cm})$, spike length $(\mathrm{cm})$, spikes per plant, spikelet per spike, seeds per spike, 1000-seed weight (g), seed yield per plot (Kg), seed yield (q/ ha) except days to $50 \%$ flowering and days to $75 \%$ maturity which had shown non-significant differences. Treatment $\mathrm{T}_{6}$ polymer + Vitavax $200 @ 2 \mathrm{~g} / \mathrm{Kg}$ of seed and $\mathrm{T}_{5}$ Vitavax $200 @ 2$ g/Kg seed had shown significant superiority for tillers per plant, plant height $(\mathrm{cm})$, spike length (cm), spikes per plant, spikelets per spike, 1000 - seed weight, seed yield per plot $(\mathrm{Kg})$, and seed yield (q/ha) over control $\left(\mathrm{T}_{1}\right)$. Polymer based seed treatment $\left(\mathrm{T}_{6}\right)$ had shown $14.7 \%$ gain in seed yield over control $\left(\mathrm{T}_{1}\right)$ followed by $13.3 \%$ under treatment $\mathrm{T}_{5}$ Vitavax $200 @$ $2 \mathrm{~g} / \mathrm{Kg}$ seed (Fig 1).

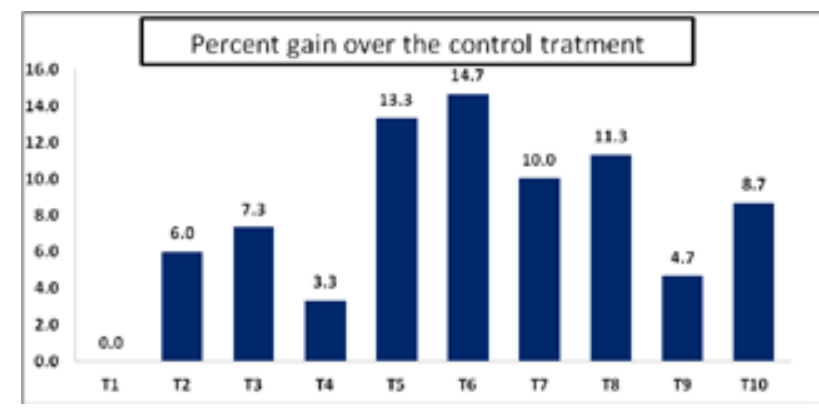

Fig. 1. Percent gain of treatments over control

It can be concluded that to get better crop performance seeds of wheat can be either be treated with polymer coating@ $3 \mathrm{ml} / \mathrm{Kg}$ of seed + Vitavax $200 @ 2$ g/Kg of seeds or Vitavax $200 @ 2$ g/Kg of seed.

\section{Acknowledgements}

The authors are thankful to the Department of Seed Science and Technology, CSKHPKV, Palampur for providing necessary laboratory facility and support for carrying out the study.

\section{Conflict of Interest}

Authors declare that they have no conflict of interests.

\section{Ethical Compliance Statement}

NA

\section{Author's Contribution}

Conceptualization of research (AT, KCD, RK); Designing of the experiments (KCD, RK, AT); Contribution of experimental materials (KCD, AT); Execution of field/lab experiments and data collection (AT, KCD, RK); Analysis of data and interpretation (KCD, RK, AT); Preparation of the manuscript (AT, KCD, RK).

\section{References}

1. Bony RK, B Rajeswari, K Jhansi and K Keshavulu. 2017. Effect of seed coating polymer on biochemical constituent of soybean (Glycine $\max \mathrm{L}$.). International Journal of Chemical Studies 5: 1663-166

2. Chikkanna CS, Timmegouda and R Ramesh. 2000. Hydrophilic polymer seed treatment on seed quality and yield in finger millet, cowpea and groundnut. Seeds and Farms 85: 39-45

3. Delouhe JC. 2005. Seed quality and performance. Seed Neres 9:34-35 
4. Freiberg JA, MP Ludwig, L Decarli, E Girotto and L Navarini. 2017. Physiological quality, initial establishment and wheat yield according to the seed treatment method. Pesquisa Agropecuária Tropical 47: 448-455. https://doi.org/10.1590/1983$40632017 \mathrm{v} 4749214$

5. Girolami V, L Mazzon, A Squartini, N Mori, M Marzaro, A Bernardo, M Greatti, C Giorio and A Tapparo. 2009. Translocation of neonicotinoid insecticides from coated seeds to seedling guttation drops: a novel way of intoxication for bees. Journal of Economic Entomology 5:1808-1815. https://doi. org/10.1603/029.102.0511

6. Miller TE. 1987. Systematics and evolution. In Wheat breeding (pp. 1-30). Springer, Dordrecht https://doi. org//10.1007/978-94-009-3131-2_1

7. Munkvold GP and JK O’Mara. 2002. Laboratory and growth chamber evaluation of fungicidal seed treatments for maize seedling blight caused by Fusarium species. Plant Disease 86:143-15. https://doi. org/10.1094/PDIS.2002.86.2.143

8. Nascimento WM, DCFS Dias and PP Silva. 2011. Seed quality and establishment of Jatroha plants in the field. Hortalicas: tecnologia de producao de sementes. Embrapa Hortalicas as Bras. 79-106

9. Raju PK. 2019. Seed treatment and polymer coating effect on germination, seedling vigour, field performance and yield of hybrid maize. MSc thesis, Department of Seed Science and Technology, Acharya N.G. Ranga Agricultural University, Guntur, India.
10. Selvakumar R, MS Saharan, S Kumar, RS Taya and I Sharma. 2015. Efficacy of fungicides as seed treatment and foliar application for managing leaf blight (Bipolaris sorokininana) on wheat (Triticum aestivum $\mathrm{L}$ ). Journal of Wheat Research 7 (2):14-18

11. Sharma J, KC Dhiman, JK Sharma, and R Kumar. 2017. Effect of seed coating on seed yield and related parameters in quality protein maize hybrid HQPM 1. Himachal Journal of Agricultural Research 43: 68-72

12. Sheoran OP, DS Tonk, LS Kaushik, RC Hasija and RS Pannu. 1998. Statistical Software Package for Agricultural Research Workers. Recent Advances in information theory, Statistics \& Computer Applications by DS Hooda \& RC Hasijia, Department of Mathematics Statistics, CCS HAU, Hisar pp 139143

13. Sumalata B, Parashivamurthy and R Siddaraju. 2017. Effect of seed coating polymers on growth and yield of maize hybrid Hema. Mysore Journal of Agricultural Sciences 51: 108-112

14. Tillmann, MAA and Miranda DM. 2006. Seed analysis. Seeds: Scientific and Technological Foundations: 159-255

15. Tiwari TN, kamal D and Singh RK. 2015. Enhancement of seed quality, growth and yield of wheat (Triticum aestivum L.) through polymer seed coating. International Journal of Agricultural Sciences 11: 99-103. DOI : 10.15740/HAS/IJAS/11.1/99-103. 